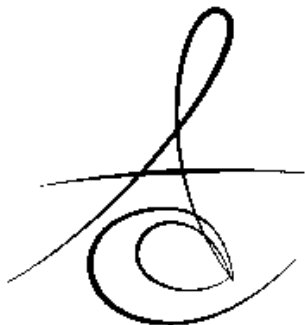

Makale Kodu/Article code: 2164

Makale Gönderilme tarihi: 02.03 .2015

Kabul Tarihi: 25.08.2015

\section{POLİKİSTİK OVER SENDROMU VE PERİODONTAL SAĞLIK ARASINDAKİ İLİ̧̧Kं}

\section{THE RELATIONSHIP BETWEEN POLICYSTIC OVARY SYNDROME AND PERIODONTAL HELTH}

\author{
Dr. Dt. Fatma KARACAOĞLU *
}

\section{ÖZET}

Polikistik over sendromu (PKOS) üreme çağındaki kadınların \%6-8 ini etkileyen yaygın bir endokrin bozukluktur. Hiperandrojenizm ve kronik anovülasyonla karakterize olan bu hastalığın etiyolojisi tam olarak bilinmemektedir. Polikistik over sendromu olan kadınlar insülin direnci, santral obezite, dislipidemi ve artmış kardiyovasküler risk faktörlerini içeren kardiyometabolik risk profiline sahiptir.

Periodontal hastalık patojenik bakteriyel mikrofloraya karşı abartıı gingival enflamasyon cevabıyla karakterize yaygın kronik enfeksiyondur. Birçok çalışmada periodontal hastalık ile metabolik sendrom, diyabet ve kardiyovasküler hastalıkları içeren sistemik problemler arasındaki ilişki değerlendirilmiştir. Periodontitis ve metabolik sendrom, sistemik enflamasyon ve insülin direnci ile ilişkilidir dolayısıyla bu iki hastalık benzer patofizyolojik yol izliyor olabilir.

$\mathrm{Bu}$ derlemenin amacl polikistik over sendromu ve periodontal sağlık arasındaki ilişki hakkında bilgi vermektir.

Anahtar kelimeler: Polikistik over sendromu, gingivitis, periodontitis

\section{ABSTRACT}

Polycystic ovary syndrome (PCOS) is a common endocrin disorder affecting $6 \%-8 \%$ of women of reproductive age. Policystic ovary syndrome is a complex disease characterized by hyperandrogenism and chronic anovulation and its etiology remains unknown. Women with policystic ovary syndrome have an adverse cardiometabolic risk profile, including insulin resistance, central obesity, dyslipidemia, and increased prevalence of cardiovascular risk factors. Accordingly, policystic ovary syndrome might be viewed as a gender-specific form of the metabolic syndrome.

Periodontal disease is a common chronic infection characterized by an exaggerated gingival inflammatory response against pathogenic bacterial microflora, resulting in alveolar bone and eventually tooth loss. Several lines of evidence established the association between periodontal disease and systemic disorders, including metabolic syndrome, diabetes, and cardiovascular disease. Because both periodontitis and metabolic syndrome are associated with systemic inflammation and insulin resistance, these two disorders may be linked through a common pathophysiologic pathway.

The aim of the present rewiev was to give information about the relationship between policystic ovary syndrome and periodontal health.

Key words: Policystic ovary syndrome, gingivitis, periodontitis

* Ankara Üniversitesi Diş Hekimliği Fakültesi Periodontoloji Anabilim Dalı 
İlk kez 1935 yllında Stein ve Leventhal tarafindan rapor edilen ${ }^{1}$ Polikistik Over Sendromu (PKOS) üreme çağındaki kadınlarda en sık görülen endokrin

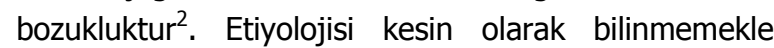
birlikte, genetik ve çevresel faktörlerin etkileşimiyle ortaya çıkan kompleks bir hastalık olarak değerlendirilebilir. Sendromun prevalansı yaklaşık \%6-8 olarak

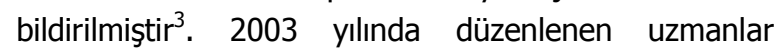
toplantısında, cushing sendromu, hiperprolaktinemi, klasik olmayan konjenital adrenal hiperplazi gibi diğer etiyolojik nedenler elendikten sonra, sendrom tanısının aşağıdaki üç kriterden ikisinin birlikteliği ile konulması önerilmiştir ${ }^{4,5}$ :

1- Oligo-anovülasyon,

2- Klinik ve/veya biyokimyasal hiperandrojenizm bulguları,

3- Ultrasonografide polikistik overler.

PKOS olan kadınlar insülin direnci, tip 2 diyabet, endotelyal disfonksiyon, santral obezite ${ }^{6-9}$, dilsipidemi ve düşük seviyeli enflamasyon ${ }^{10-12}$ gibi artmış kardiyovasküler risk faktörlerini içeren kardiyometabolik risk profiline sahiptir. Dolayısıyla PKOS metabolik sendromun cinsiyete özel (kadınlara özgü) formu olarak düşünülebilir ${ }^{13}$.

PKOS olan hastaların yaklaşık \%25-60'ında insülin direnci ve hiperinsülinemi saptanmıştır. ${ }^{14,15} \mathrm{Bu}$ hastalarda bozulmuş glikoz toleransı ve tip 2 diyabet prevalansı değişik çalışmalarda \%35-40 arasında bulunmuştur ${ }^{7,8,16}$. Bu nedenle PKOS tip 2 diyabet gelişimi için bağımsız bir risk faktörü olarak kabul edilmekte ve tüm PKOS hastalarında diyabet yönünden tarama yapılması önerilmektedir. Bununla birlikte, her PKOS hastasında insülin direnci olmadığı gibi insülin direnci ölçümü PKOS tanı kriterleri arasında yer almaz ${ }^{17}$.

PKOS' nda obezite görülme sıklığı \%40-60 olarak bildirilmektedir ${ }^{3,18}$. Obezite sıklıkla bel/kalça oranının arttığı santral obezite tipinde olup, PKOS olan hastalara ek riskler getirmektedir ${ }^{19}$. Bununla birlikte obezitenin PKOS'nun fenotipik ekspresyonunu etkilediği ve hiperandrojenizm ve kronik anovülasyonun patofizyolojisinde önemli rol oynayabildiği iyi bilinmektedir ${ }^{20}$.

Sendromda tromboz eğiliminin artmış olabileceğini gösteren çalışmalar da mevcuttur ${ }^{21,22}$. Ancak PKOS'unda artmış/erken kardiyovasküler mortalite veya morbidite literatürde direk olarak gösterilmemiştir $^{23}$. PKOS genel olarak endometriyum kanseri için de risk faktörü olarak bilinmesine rağmen destekleyen epidemiyolojik veriler sınırlıdır.

Hem hiperinsülinemi hem de obezite hiperandrojenezim gelişimi ve devamlılığı ile yakıdan ilişkili görünmektedir ${ }^{24,25}$. Artmış androjen seviyeleri hedef dokuda, özellikle kaslarda, insülin hassasiyetine direk etki ederek insülin direnci gelişimine yol açabiliir ${ }^{26}$. PKOS'unda C Reaktif Protein (CRP) seviyelerindeki artış, hastalı̆ın insülin direnci ile ilişkili düşük seviyeli kronik enflamasyonla da ilişkili olabileceğini göstermektedir ${ }^{10}$.

Periodontal hastalık patojenik bakteriyel mikrofloraya karşı oluşan abartılı gingival enflamatuar yanıtla karakterize, alveol kemik ve diş kaybıyla sonuçlanabilen yaygın kronik bir enfeksiyondur. Periodontitis için 3 major risk faktörü mikrobiyal dental biyofilm, sigara, ve diyabettiir ${ }^{27,28}$. Birçok çalışmada periodontitis ile metabolik sendrom, diyabet ve kardiyovasküler hastalıkları (KVH) kapsayan sistemik hastalıklar arasındaki ilişki değerlendirilmiştir ${ }^{29,30}$. Hem periodontal hastalık hem de metabolik sendrom, sistemik enflamasyon ve insülin direnci ile ilişkili olduğu için bu hastalıklar benzer patofizyolojik yolu izliyor olabiliir ${ }^{29}$.

Gingivitisi de kapsayan periodontal hastalıklar subgingival bölgede kolonize olan, Tümör Nekrotizan Faktör-a (TNF-a), İnterlökin-6 (IL-6) gibi doku yıkımına sebep olan proenflamatuar sitokinlerin lokal ve sistemik salımına yol açan enfeksiyöz hastalıklardır. PKOS'nun oksidatif streste artış ve sistemik enflamasyonla ilişkili olduğunu gösteren kanıtların artması bu fikri desteklemektedir. Sağlıklı kontrol bireyleri ile karşılaşııııldığında PKOS olan kadınlarda lipid peroksidasyon markırlarında, CRP ve enflamatuar sitokin seviyelerinde artış olduğu, benzer şekilde kan lenfosit ve monosit yüzdelerinin de daha fazla olduğu gözlenmiş̧ir ${ }^{31,32}$. Bununla birlikte bu iletişimin sebebi henüz belirlenememiştir. Bu durum kronik enfeksiyonun PKOS etiyolojisinde yer alabileceği hipotezini desteklemektedir.

Özçaka ve arkadaşları ${ }^{33}$ PKOS ve gingivitisi olan kadınlarda serum TNF-a, TNF-a reseptör (TNF-aRs) ve IL-6 kosantrasyonlarını PKOS olan fakat periodontal olarak sağlıkı bireylerden ve sistemik ve periodontal olarak sağlıkı bireylerden daha yüksek bulmuştur. Araştırmacılar PKOS ve gingivitisin sinerjistik etki göstererek TNF sistemi aktive ettiğini ileri sürmüşlerdir. IL-6 ve TNF-a nın cep SIVISI konsantrasyonları birbiriyle güçlü korelasyon gösterir ve gingivitisin klinik 
parametresi olarak kabul edilebilir. TNF-aRs ve klinik parametreler arasında da yüksek korelasyon vardır. Bu durumun PKOS veya periodontal hastalığın boyutu için nitelendirilebilir olup olmadığının değerlendirilmesi zordur. Hem düşük seviyeli kronik enflamasyonun hem de insülin direncinin PKOS olan kadınlarda artışının PKOS durumundan öte artan santral yağ kilo fazlalığı ile ilişkili olabileceği ileri sürülmüştür ${ }^{34}$.

Knebel ve arkadaşları ${ }^{35}$ IL-6 ve TNF-a seviyelerinin obez olmayan kontrol grubu kadınlarla karşılaştırıldığında obez ve PKOS olan hastalarda arttığını fakat İnterlökin-17 A (IL-17A) seviyesinin değişmeden kaldığını bulmuştur. PKOS olan kadınlarda IL-6 ve TNF-a nın artmış seviyeleri IL-17 sitokin ekspresyonunu modüle etmede çalışabilir ve bu hastalık patogenezinde önemli rol oynayabilir ${ }^{36}$. Özçaka ve $\mathrm{ark}^{36}$ obez olmayan kadınlarda IL-17 ailesi sitokinlerinin lokal ve sistemik konsantrasyonlarında PKOS'nun etkisini değerlendirmiş ve PKOS ile bu sitokinler ve gingivitis arasında bir ilişki olup olmadığını incelemişlerdir. Araştırmacılar IL-17 seviyelerinin obez olmayan PKOS'lu kadınlarda değiştiğini ve bu durumun gingival enflamasyonu etkileyebileceğini rapor etmişlerdir.

Gingivitisin PKOS olan kadınlarda sağlıklı kadınlardan daha sık görüldüğü rapor edilmiştir ${ }^{37}$. Bununla birlikte gingivitis kemik kaybıyla ilişkili değildir ve PKOS olan ve PKOS+gingivitisli kadınlarda artan IL-17A ve IL-17F seviyeleri özellikle bunların periodontal hastalıkla ilgili ateroskleroz, KVH gibi diğer kronik enflamatuar durumlarda önemli rol oynayabileceğini göstermektedir $^{38}$. Bununla birlikte PKOS'nun periodontitis gelişimde etkisi olup olmadığı belirlenmemiştir.

Mevcut deliller oksidatif stresin periodontitis, metabolik sendrom, diyabet ve KVH komponentleri ile ilişkisinde bir bağlantı olabileceğini göstermektedir ${ }^{39}$. Oksidatif stres periodontitis süresince $\operatorname{artar}^{40,41}$. Oksidatif stresin bir belirteci olarak artmış cep sIVıSı miyeloperoksidaz seviyeleri (MPO) bölgelerdeki gingivitis ve periodontitisi gösterir ${ }^{42,43}$. Dursun ve arkadaşlarının $^{37}$ zayıf ve normal glukoz toleransı olan sağlıkı kadınlarla PKOS olan kadınları karşılaştırdıkları çalışmalarında PKOS olan kadınlarda serum nitröz oksit (NO) seviyesi değişmezken cep sıvısında NO ve MPO seviyeleri artmıştır. Bu durum lokal/periodontal oksidatif stresi göstermektedir. Ayrıca çalışmanın bulguları benzer yaş ve kilodaki kadınlarla karşılaştırılan PKOS olan kadınlarda artmış periodontal indeks skorlarının periodontal sağlığın kötüleştiğini ve gingival enflamas- yonun yaygın bulgu olduğunu ortaya koymaktadır. Bu durum yüksek cep sıvısı hacmiyle desteklenmektedir ${ }^{44}$. $\mathrm{Bu}$ hastalarda radyografik analizlerde herhangi bir periodontal kemik kaybı görülmemiştir bu da periodontal hastalığın dişeti seviyesinde olduğunu göstermektedir.

Reaktif oksijen türlerinin PKOS hastalarında sistemik oksidatif strese sebep olması insülin direnci gelişimini $^{45}$ ve ileri glukasyon ürünlerinin üretimini ${ }^{46}$ uyarır. Periodontitiste artmış cep sıvısı NO düzeyi lokal oksidatif stresin belirtecidir. Reaktif oksijen türleri normal hücresel sinyal mekanizmalarını bozan yıkıma sebep olarak periodontal hastalık ilerlemesinde önemli rol oynar ${ }^{47}$. PKOS hastalarında lokal etki sistemik oksidatif stres varlığı ile desteklenebilir. Bu nedenle, periodontal yıkım konakta sistemik şartlar üzerinde birleşen lokal faktörlerin kümülatif etkisi ile olabilir. İleri glukasyon ürünleri periodontal hastalık gelişimi ve şiddeti üzerinde zararlı etkilere sahiptir. Bu bulgular dikkate alındığında PKOS'nun zaten plak varlığından etkilenen periodontal durumu, reaktif oksijen türleri, insülin direnci, ileri glukasyon ürünleri ve sistemik hormonal seviyeleri içeren yollar aracılığı ile etkileyebileceği öne sürülebilir ${ }^{48}$.

Kadın seks steroid hormonları yani östrojen, progesteron ve androjenler periodontal hastalığı etkileyen önemli modifiye edici faktörlerdir ${ }^{49}$. Oral dokular bu hormonlar için dişetini direk etkiye hedef organ haline getiren reseptörlere sahiptir ${ }^{50}$. Bu hormonlar keratinositlerin ve fibroblastların büyüme ve farklılaşmasına sebep olarak hücresel proliferasyonu etkiler ve kemik bağlantısında rol oynar, dolayısıyla kemik kütlesini etkiler. Hatta kan damarlarında ve immünolojik faktörlerde değişikliklere sebep olur ${ }^{51,52}$. Sistemik hormonal durumun bu etkisi periodontal hastalık sınıflandırmasında da onaylanmıştır ki bunlar puberte ilişkili gingivitis, menstrual siklus ilişkili gingivitis ve hamilelikle ilişkili gingivitis gibi hormon ilişkili hastaIıkları kapsar ${ }^{53}$. PKOS vücutta çeşitli hormon seviyelerini etkiler. PKOS olan kadınlar insülin direnci ile kombine androjen fazlalığına sahiptir.

Asnani ve arkadaşları ${ }^{48}$ yayınladıkları vaka raporunda dişeti büyümesi şikayeti ile gelen PKOS olan kadın hastada dişetinde enflamasyon ve dişeti büyümesi varlığı için dişetinde östrojen ve progesteron reseptörlerini değerlendirmişlerdir. Yapılan tedavi sonrasında mükemmel oral hijyene rağmen dişeti büyümesi azalmamıştır. Yazarlar enflamasyon plak 
sebebiyle olsa bile steroid hormonların sinerjistik rol oynadığını, dolayısıyla sundukları vakada reaktif oksijen türleri ve inflamatuar sitokinlerin dişeti büyümesi ve enflamasyona sebep olduğunu ileri sürmüşlerdir.

Periodontal hastalık $\mathrm{KVH}^{54}$, romatoit artrit ${ }^{55}$, diyabet $^{56}$ ve obstrüktif respiratuar hastalıkların ${ }^{57}$ başlaması ve ilerlemesinde bir risk faktörü olarak gösterilmiştir. CRP çeşitli sistemik hastalıklar için artan risk faktörü ile ilişkili sistemik enflamasyon markırıdır ${ }^{58,59}$ ve periodontitis artmış CRP seviyesi ile ilişkilidir. Dolayısıyla CRP'nin periodontitis ve bu sistemik hastalıklar arasında ilişkinin olası mediatörü olabileceği kabul edilir $^{60}$. Önceki çalışmalarda PKOS ve periodontitis arasındaki olası ilişki ve PKOS'nun gingival enflamasyon üzerine etkisi incelenmiştir ${ }^{27,36,37}$. Bununa birlikte tıbbi tedavi durumu, sendrom tedavisinde kullanılan ilacın tipi ve süresi dikkate alınmamıştır. Porwal ve arkadaşları ${ }^{61}$ PKOS olan kadınlarda tedavi görüp görmediği dikkate alınarak high sensitif CRP (hsCRP) aracılığı ile periodontal durum ve sistemik eflamasyon düzeyini araştırmıştır. Yazarlar yeni teşhis konulan PKOS olan kadınların sistemik olarak sağlıklı kadınlar ve medikal tedavi gören (oral kontraseptif+ metformin+ hayat tarzı modifikasyonu) PKOS olan kadınlarla karşılaştırıldığında daha yüksek cep derinliği, klinik ataçman kaybı, BOP pozitif bölge sayısı, bel çevresi, serum hsCRP seviyesine sahip olduğunu, tedavi gören PKOS olan kadınların yeni teşhis konanlarla karşılaştırıldığında da periodontal yıkım ölçümleri ve bel çevresi ölçümleri daha düşük olduğunu, ve yeni teşhis konan hastalarda periodontitis prevalansı daha yüksek bulunduğu için bu hastalarda periodontitis gelişme olasılığının daha yüksek olduğunu rapor etmiştir.

Çalışmalar ${ }^{62,63}$ PKOS olan kadınlarda medikal tedavinin sonucu olarak vücut kütle indeksi, bel kalça oranı ve bel çevresinde anlamlı azalma rapor etmiştir. Nickalas ve arkadaşlarının ${ }^{64}$ kapsamlı bir derlemesi uzun dönem diyet, kilo azalması ve fizyolojik egzersizle CRP, IL-6, IL-8, TNF-a düşüşü için delil sağlamıştır. Ek olarak Papunen ve arkadaşları ${ }^{65}$ metforminin hsCRP, bel çevresi ve bel kalça oranı azalmasında anlamlı etkisi olduğunu göstermiş ve CRP'nin PKOS olan kadınlarda tedavi etkinliğini değerlendirmede bir markır olarak kullanılabileceğini ileri sürmüştür. Tedavi gören PKOS hastalarında yeni teşhis konulan hastalara göre sistemik enflamasyonun daha düşük seviyeleri ve daha düşük periodontal yıkım indeksleri medikal tedavinin olası bir sonucu olabilir ve doğrulanması gereklidir.

Periodontal hastalıklar için primer etyolojik faktör dental plakta yer alan P. Gingivalis, T. Denticola, T. Forsythia. A. Actinomicetemcomitans (Aa) ve P. İntermedia türleri gibi mikroorganizmalardır ki bunlar tükürükte de tespit edilebilir ${ }^{66}$. Özellikle kadın steroid hormonlarının oral flora kompozisyonu üzerine etkisi puberte, menstruasyon, hamilelik ve oral kontraseptif kullanımında rapor edilmiştir ${ }^{67}$. Periodotal hastalıkların düşük dereceli kronik sistemik enflamasyona sebep olduğu dikkate alındığında ${ }^{68}$ PKOS gibi hormonal düzensizliklerle olan ilişkiyi göz önünde bulundurmak gereklidir. PKOS'nda hormonal değişiklikler putatif periodotal patojenlerin tükrük seviyesini, sistemik antikor cevaplarını etkileyebilir.

Serum antikor seviyeleri periodontal sağlık veya hastalığın ilerleyişi ile ilişkili olabildiği için ${ }^{69}$, ölçümleri oral floraya karşı konak cevabı üzerinde bilgi sağlar. Sistemik olarak sağlıkı bireylerde subgingival floradaki farklılıklara rağmen periodontal durumla ilgili serum antikor seviyelerinde büyük farklılıklar yoktur ${ }^{70}$. Bununla birlikte, sistemik sağlık durumu zayıf glisemik kontrollü hastalarda olduğu gibi serum antikor cevaplarını değiştirebilir ${ }^{71}$. Bu bağlamda, tip 2 diyabette $\mathrm{C}$. Rectusa karşı serum antibody düzeyi artarken, diyabetik sağlık durumuna bakmaksızın periodontitiste P. Gingivalise karşı $\operatorname{artar}^{72}$. Güncel deliller $A a, P$. Gingivalis, P. İntermedia nın artan serum antikor düzeylerinin artmış koroner kalp hastalığı riski ile ilişkili olduğunu göstermiştir ${ }^{73}$.

Akcalı ve arkadaşları $^{74}$ P. Gingivalis, T. Denticola, T. Forsythia, $\mathrm{Aa}$, P. İntermedia, $\mathrm{F}$. Nucleatum ve S. Oralisi içeren 7 oral takson düzeyini ve özellikle gingivitis varlığında PKOS olan kadınlarda serum antikor cevaplarıyla ilişkisini araştırmıştır. Çalışmanın bulguları Aa., T. Denticola hariç çalışılan putatif periodontal patojenlerin pek çoğunun sağlıkı kadınlarla karşılaştırıldığında PKOS ve gingivitisli kadınlarda arttığını göstermiştir. PKOS P. Gingivalis ve $F$. Nucleatum seviyelerinde ve gingival enflamasyonla ilişkide arttırıcı etkiye sahip görülmüştür. Sistemik sağlıkta gingival enflamasyon (BOP skoruyla değerlendirilen) ve çalışılan türlere karşı serum antikor seviyeleri arasında pozitif korelasyon olmamasına rağmen PKOS varlığında sadece $P$. gingivalisle pozitif korelasyon bulunmuştur. Çalışma sonuçları oral mikrobiyata ve gingival eflamasyon arasında bu

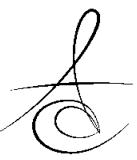


endokrin bozuklukla dozu arttırılacak pozitif ilişkiyi ortaya koymaktadır.

\section{SONUC}

Hiperandrojenik kronik anovülasyonla karakterize PKOS, kompleks bir metabolik ve endokrin bozukluktur. Görülme sıklığı ve taşıdığı uzun dönem sağlık riskleri nedeniyle günümüzde bir halk sağlığı problemi olarak ele alınabilir. PKOS'nun etyopatogenezi net olarak bilinmediği için günümüzde mevcut tedavi seçenekleri de genellikle semptomatiktir. PKOS ve periodontal sağlık ile ilgili yapılan çalışmaların sonuçları, PKOS' nda gingivitisin yaygın bulgu olduğunu, periodontitis yatkınlığının anlamlı oranda artabileceğini ve lokal/periodontal oksidan durumunun PKOS da etkili olabileceğini göstermektedir. Bununla birlikte, enflamatuar periodontal hastalıklar ve PKOS arasındaki olası ilişkiyi açıklayacak longitudinal, çok merkezli, randomize kontrollü ve uzun takip süreleri olan ilave çalışmalar gerekmektedir.

\section{KAYNAKLAR}

1- Stein JF, Leventhal ML. Amonorrhea associated with bilateral polycystic ovaries. Am J Obstet Gynecol 1935; 29: 181-91

2- Pişkinpaşa S, Yıldız BO. Polikistik over sendromu. Hacettepe Tıp Dergisi 2005; 36: 168-74

3- Azziz R, Woods KS, Reyna R, Key TJ, Knochenhauer ES, Yıldız BO. The prevalence and features of the polycystic ovary syndrome in an unselected population. J Clin Endocrinol Metab 2004; 89: 2745-9

4- Rotterdam ESHRE/ASRM Sponsored PCOS Consensus Workshop Group. Revised 2003 consensus on diagnostic criteria and long-term health risks related to polycystic ovary syndrome. Fertil Steril 2004; 81:19-25

5- Rotterdam ESHRE/ASRM Sponsored PCOS Consensus Workshop Group. Revised 2003 consensus on diagnostic criteria and long-term health risks related to polycystic ovary syndrome. Hum Reprod 2004; 19: 41-7

6- Dunaif A. Insulin resistance and the polycystic ovary syndrome: Mechanism and implications for pathogenesis. Endocr Rev 1997; 18: 774-800
7- Ehrmann DA, Barnes RB, Rosenfield RL, Cavaghan MK, Imperial J. Prevalence of impaired glucose tolerance and diabetes in women with polycystic ovary syndrome. Diabetes Care 1999; 22: 141-6

8- Legro RS, Kunselman AR, Dodson WC, Dunaif A. Prevalence and predictors of risk for type 2 diabetes mellitus and impaired glucose tolerance in polycystic ovary syndrome: A prospective, controlled study in 254 affected women. J Clin Endocrinol Metab 1999; 84: 165-9

9- Paradisi G, Steinberg HO, Hempfilling A, Cronin J, Hook G, Snepard MK, Baron AD. Polycystic ovary syndrome is associated with endotelial dysfunction. Circulation 2001; 103: 1410-5

10-Kelly CC, Lyall H, Petrie JR, Gould GW, Connell JM, Sattar N. Low grade chronic inflammation in women with polycystic ovary syndrome. J Clin Endocrinol Metab 2001; 86: 2453-5

11-Diamanti-Kandarakis $\mathrm{E}$, Alexandraki K, Protogerou A, Piperi C, Papamichael C, Aessopos A, Lekakis J, Mavrikakis $M$. Metformin administration improves endothelial function in women with polycystic ovary syndrome. Eur J Endocrinol 2005; 152: 74956

12-Diamanti-Kandarakis E, Paterakis T, Alexandraki K,Piperi C, Aessopos A, Katsikis I, Katsilambros N, Kreatsos G, Panidis D. Indices of low-grade chronic inflammation in polycystic ovary syndrome and the beneficial effect of metformin. Hum Reprod 2006; 21: $1426-31$

13-Sam S, Dunaif A. Polycystic ovary syndrome: syndrome XX? Trends Endocrinol Metab 2003; 14: 365-70

14-Dunaif A, Segal KR, Futterweit W, Dobrjansky A. Profound peripheral insulin resistance, independent of obesity, in polycystic ovary syndrome. Diabetes 1989; 38: 1165-74

15-Legro RS, Finegood D, Dunaif A. A fasting glucose to insulin ratio is a useful measure of insulin sensitivity in women with polycystic ovary syndrome. J Clin Endocrinol Metab 1998; 83: 17987

16-Weerakiet S, Srisombut C, Bunnag P, Sagtong S, Chuansoongnoen N, Rojanasakul A. Prevalance of type 2 diabetes mellitus and impaired glucose tolerance in Asian women with polycystic ovary syndrome. Int J Gynaecol Obstet 2001; 75: 177-84 
17-Yıldız BO, Gedik O. Assessment of glucose intolerance and insulin sensitivity in polycystic ovary syndrome. Reprod Biomed Online 2004; 8: 649-56

18-Goldzieher JW, Green JA. The polycystic ovary I. Clinical and histological features. J Clin Endocrinal Metab 1961; 2: 325-38

19-Bjorntorp P. The associations between obesity, adipose tissue distribution and disease. Acta Med Scan Suppl 1988; 723:121-34

20-Yıldız BO, Knochenhauer ES, Azziz R. Impact of obesity on the risk for. J Clin Endocrinal Metab 2008; 93: 162-8

21-Kelly CJ, Lyall H, Petrie JR, Gould GW, Connell MC, Rumley A, Lowe DO, Sattar N. A specific elevation in tissue plasminogen activator antigen in women with polycystic ovarian syndrome. J Clin Endocrianol Metab 2002; 87: 3287-90

22-Yıldız BO, Haznedaroğlu IC, Kirazlı S, Bayraktar M. Global fibrinolytic capacity is decreased in polycystic ovary syndrome, suggesting a prothrombotic state. J Clin Endocrianol Metab 2002; 87: 3871-5

23-Legro RS. Polycystic ovary syndrome and cardiovascular disease: a premature association? Endocr Rev 003; 24: 302-12

24-Franks S. Polycystic ovary syndrome. N Engl J Med 1995; 333: 853-61

25-Poretsky L. On the paradox of insulin-induced hyperandrogenism in insulin-resistant state. Endocr rev 1991; 12: 3-13

26-Bjorntorp P. Hyperandrogencity in women-a prediabetic condition? J Intern Med 1993; 234: 579-83

27-Nishida N, Tanaka M, Hayashi N, Nagata H, Takeshita T, Nakayama $K$. Determination of smoking and obesity as periodontitis risks using the classification and regression tree nethod. J Periodontol 2005; 76: 923-8

28-Taylor GW, Burt BA, Becker MP, Genco RJ, Shlossman M, Knowler WC, Pettitt DJ. Noninsulin dependent diabetes mellitus and alveolar bone loss progression over 2 years. J Periodontol 1998; 69: 76-83
29-D'Aiuto F, Sabbah W, Netuveli G, Donos N, Hingorani AD, Deanfield J, Tsakos G. Association of the metabolic syndrome with severe periodontitis in a large U.S. population-based survey. J Clin Endocrinol Metab 2008; 35: 3989-94

30-Kinane D, Bouchard P; Group E of European Workshop on Periodontology. Periodontal disease and health: Consensus report of the Sixth European Workshop on Periodontology. J Clin Periodontol 2008; 35 (Suppl. 8): 333-7

31-Sabuncu T, Vural H, Harma M. Oxidative stress in polycystic ovary syndrome and its contribution to the risk of cardiovascular disease. Clin Biochem 001; 34: 407-13

32-Orio F Jr, Palomba $\mathrm{S}$, Cascella $\mathrm{T}$, Di Biase S, Manguso F, Tauchmanovà L, Nardo LG, Labella D, Savastano S, Russo T, Zullo F,Colao A, Lombardi G. The increase of leukocytes as a new putative marker of low-grade chronic inflammation and early cardiovascular risk in polycystic ovary syndrome. J Clin Endocrinol Metab 2005; 90:2-5

33-Özçaka Ö, Ceyhan BÖ, Akcali A, Biçakci N, Lappin $\mathrm{DF}$, Buduneli $\mathrm{N}$. Is there an interaction between polycystic ovary syndrome and gingival inflammation? J Periodontol 2012; 83: 1529-37

34-Puder JJ, Varga S, Kraenzlin M, De Geyter C, Keller $U$, Müller B. Central fat excess in polycystic ovary syndrome: relation to low-grade inflammation and insulin resistance. J Clin Endocrinol Metab 2005; 90: 6014-21

35-Knebel B, Janssen OE, Hahn S, Jacob S, Gleich J, Kotzka J, Muller-Wieland D. Increased low grade inflammatory serum markers in patients with polycystic ovary syndrome (PKOS) and their relationship to PPARgamma gen variants. Exp Clin Endocrinol Diabetes 2008; 116: 481-6

36-Özçaka Ö, Buduneli N, Ceyhan BÖ, Akcali A, Hannah V, Nile C, Lappin DF. Is interleukin-17 involved in the interaction between polycystic ovary syndrome and gingival inflammation? J Periodontol 2013; 84: 1827-37

37-Dursun E, Akalın FA, Güncü GN, Çınar T, Aksoy NY, Tözüm TF, Kılınç K, Yıldız BO. Periodontal disease in polycystic ovary syndrome. Fertill Steril 2011; 95: 320-3 
38-Butcher M, Galkina E. Current viewson the functions of interleukin-17A-prodcing cells in atherosclerosis. Thomb Haemost 2011; 106: 78795

39-Bullon P, Morillo JM, Ramirez-Tortosa MC, Quiles $\mathrm{JL}$, Newman HN, Battino M. Metabolic syndrome and periodontitis: Is oxidative stress a common link? J Dent Res 2009; 88: 503-18

40-Akalin FA, Baltacioğlu E, Alver A, Karabulut E. Lipid peroxidation levels and total oxidant status in serum, saliva and crevicular fluid in patients with chronic periodontitis. J Clin Periodontol 2007; 34: 558-65

41-Sculley DV, Langley- Evans SC. Periodontal disease is associated with lower antioxidant capacity in whole saliva and evidence of increased protein oxidation. Clin Sci (Lond) 2003; 105: 167-72

42-Wei PF, Ho KY, Ho YP, Wu YM, Yang YH, Tsai CC. The investigation of glutathione peroxidase, lactoferrin myeloperoxidase and interleukin-1beta in gingival crevicular fluid: implications for oxidative stress in human periodontal diseases. ] Periodontal Res 2004; 39: 287-93

43-Yamalik N, Caglayan F, Kilinc K, Kılınç A, Tumer C. The importannce of data presentation regarding gingival crevicular fluid myeloperoxidase ad elastase-like activity in periodontal disease annd health status. J Periodontol 2000; 71: 460-7

44-Rudin HJ, Overdiek HF, Rateitschak KH. Correlation between sulcus fluid rate and clinical and histological inflammation of the marginal gingiva. Helv odontol Acta 1970; 14: 21-6

45-Gonzalez F, Rote NS, Minium J, kirwan JP. Reactive oxygen species-induced oxidative stress in the development of insulin resistance and hyperandrogenism in polycystic ovary syndrome. J Clin endocrinol Metab 2006; 91: 336-40

46-Dimanti-Kandarakis E, Katsikis I, Piperi C, Kandaraki E, Piouka A, Papavassiliou AG, Panidis D. Increased serum advanced glycation endproducts is a distinct finding in leal women with polycystic ovary syndrome (PCOS). Clin Endocrinol 2008; 69: 634-41

47-D'Aiuto F, Nibali L, Parkar M, Patel K, Suvan J, Donos N. Oxidative stress, systemic inflammation, and severe periodontitis. J Dent Res 2010; 89: 1241-46
48-Asnani KP, Hingorani D, Kheur S, Deshmukh VL, Romanos GE. Expression of nuclear receptors of gingiva in polycystic ovary syndrome: a preliminary case study. Aust Dent J 2014; 59: 252-7

49-Mascarenhas P, Gapski R, Al-Shammari K, Wang $\mathrm{HL}$. Influence of sex hormones on the periodontium. J Clin Periodontol 2003; 30: 671-81

50-Hosseni FA. Immunıhistochemical analysis of oestrogen annd progesterone receptor expression in gingival lessions. Iranian J Public Health 2006; 35: $38-41$

51-Whitaker SB, Bouquot JE, Alimario AE, Whitaker TJ Jr. Identification and semiquantification of oestrogen and progesterone receptors in pyogenic granulomas of pregnancy. Oral Surg Oral Med Oral Pathol 1994; 78: 755-60

52-Markau E, Elena B, Lazaros T, Antonios K. The influennce of sex steroid hormones on gingiva of women. Open dent J 2009; 3: 114-9

53-Armitage C. Development of a classification system for periodontal disease and conditions. Ann Periodontol 1999; 4: 1-6

54-Demmer RT, Desvarieux M. Periodontal inefctions and cardiovascular disease: The heart of the matter. J am Dent Assoc 2006; 137: 14S-20S

55-Ribeiro J, Leao A, Novaes AB. Periodontal infections as a possible severity factor for rheumatoid arthritis. J Clin Periodontol 2005; 32: 412-6

56-Grossi SG, Genco RJ. Periodontal disease and diabetes mellitus: A two-way relationship. Ann Periodotol1998; 3: 51-61

57-Hayes C, Sparrow D, Cohen M, Vokonas PS, Garcia RI. The association between alveolar bone loss ad pulmonary function: The VA dental longitudinal study. Ann Periodontal 1998; 3: 257-61

58-Slade GD, Offenbacher S, Beck JD, Heiss J, Pankow JS. Acute phase inflammatory response to periodontal disease in the US population. J Dent Res 2000; 79: 49-57

59-Joshipura KJ, Wand HC, Merchant AT, Rimm EB. Periodontal disease ad biomarkers related to cardiovascular disease. J Dent Res 2004;83: 151-5

60-Pitiphat W, Savetsilp W, wara-Aswapati N. Creactive protein associated with periodontitis in a Thai population. J Clin Periodontol 2008; 35: 120-5 
61-Porwal S, tewari S, sharma RK, Singal S, narula SC. Periodontal status and high sensitive c-reactive protein levels in polycystic ovary syndrome: with and without medical treatment. J Periodontol 2014; 85: 1380-9

62-Elter K, Imir G, Durmusoglu F. Clinical, endocrine and metabolic effects of etformin added to ethinylestradiol-cyproterone acetate in non-obese women with polycystic ovary syndrome: a randomized controlled study. Hum reprod 2002; 7 : 1729-37

63-Hoeger K, Davidson K, Kochman L, Cherry T, Kopin $L$, Guzick DS. The impact of metformin, oral contraceptives and lifestyle modification on polycystic ovary syndrome in obese adolescent women in two randomized, placebo-controlled trials. J Clin Endocrinol Metab 2008; 11: 4299-306

64-Nickalas BJ, You T, Pahor M. Bihavorial treatments for chronic systemic inflammation: effects of diatery weight loss and exercise training. Can Med Assoc J 2005; 172: 1199-209

65-Papunen LM, Rautio K, Ruokonen A, Prijo H, Puukka M, Tapanainen JS. Metformin reduces Creactive protein levels in women with polycystic ovary syndrome. J Clin Endocrinol Metab 2003; 88: 4649-54

66- Kinney JS, Morelli T, Braun T, Ramseier CA, Herr $A E$, Sugai JV, Shelburne CE, Rayburn LA, Singh AK, Giannobile WV. Saliva/pathogen biomarker signatures and periodontal disease progression. J Dent Res 2011; 90: 752-8

67-Kumar PS. Sex and subgingival microbiome: do female sex steroides affect periodontal bacteria? Periodontol 2000 2013; 61: 103-24

68-Moutsopoulos NM, Madinos PN. Low-grade inflammation in chronic infectiosu disease: paradigm of periodontal infections. Ann N Y Acad Sci 2006; 1088: 251-64

69-Hwan AM, Stoupel J, Celenti R, Demmer RT, Papapanou PN. Serum antibody respomses to periodontal microbiatain chronic and aggressive periodontitis: A postulate revisited. J Periodontol 2013; 85: 592-600

70-Tanner AC, Kent RL Jr, MaidenMF, Macuch PJ, Taubman MA. Serum IgG reactivity to subgingival bacteria in initial peirodontitis, gingivitis and healthy subjects. J Clin periodontol 2000; 27: 47380
71-Awartani F. Serum immunoglobulin levels in type 2 diabetes patients with chronic periodontitis. J Contemp Dent 2010; 11: 1-8

72-Ebersole JL, Holt SC, Hansard R, Novak MJ. Microbiologic and immunologic characteristics of periodontal disease in Hispanic americans with type 2 diabetes. J Periodontol 008; 79: 637-46

73-Ueno M, Izumi $Y$, Kawaguchi $Y$, Ikeda $A$, Iso $H$, Inoue $\mathrm{M}$, Tsugane $\mathrm{S}$. Prediagnostic plasma antibody levels to periodontopathic bacteria and risk of coronary heart disease. Int Heart J 012; 3: 209-14

74-Akcalı A, Bostanci, Özçaka Ö, Ceyhan BÖ, Gümüş $P$, Buduneli N, Belibasakis GN. Association between poycystic ovary syndrome, oral microbiata and systemic antibody responses. PLoS One. 2014;9:e108074.

\section{Yazışma Adresi}

Dr. Dt. Fatma KARACAOĞLU

Ankara Üniversitesi

Diş Hekimlşği Fakültesi

Periodontoloji A.D.

06500 Çankaya, Ankara.

e-mail: fboke@ankara.edu.tr 